\title{
EFEKTIVITAS SLOW STROKE BACK MASSAGE DENGAN MENGGUNAKAN MINYAK ESENSIAL KENANGAN (CANANGA ODORATA) DAN MINYAK ESENSIAL LAVENDER (LAVANDULA ANGUSTIFOLIA) TERHADAP PENURUNAN TEKANAN DARAH PADA LANSIA DENGAN HIPERTENSI
}

\section{EFFECTIVENESS SLOW STROKE BACK MASSAGE USING YLANG ESSENTIAL OIL (CANANGA ODORATA) AND LAVENDER ESSENTIAL OIL (LAVANDULA ANGUSTIFOLIA) TO DECREASE BLOOD PRESSURE IN ELDERLY WITH HYPERTENSION}

Ni Wayan Trisnadewi1, Theresia Anita Pramesti2, I Made Sudarma Adiputra3. STIKes Wira Medika Bali1,2,3

\begin{abstract}
ABSTRAK
Pendahuluan: Tingginya angka kejadian hipertensi pada lansia menuntut peran tenaga kesehatan untuk melakukan upaya pencegahan komplikasi yang dapat timbul akibat hipertensi, salah satunya adalah slow stroke back massage. Manfaat dari slow stroke back massage adalah untuk mengurangi ketegangan sehingga dapat menurunkan toleransi nyeri dan ansietas. Metode: Desain penelitian yang digunakan dalam penelitian ini adalah control group pretest posttest design. Jumlah sampel dalam penelitian adalah 30 sampel yang dibagi menjadi 2 kelompok masing-masing 15 orang responden. Teknik sampling yang digunakan adalah purposive sampling. Hasil: Hasil penelitian menunjukkan setelah dilakukan uji Independent T Test pada tekanan darah sistole didapatkan signifikansi $0,000<0,05$ yang berarti terdapat perbedaan penurunan tekanan darah sistole setelah pemberian slow stroke back massage dengan menggunakan minyak esensial kenanga dan lavender, sedangkan pada tekanan darah diastole didapatkan signifikansi 0,001 < 0,05 yang berarti terdapat perbedaan penurunan tekanan darah diastole setelah pemberian slow stroke back massage dengan menggunakan minyak esensial kenanga dan lavender. Diskusi: Efek eugenol yang hanya terdapat pada minyak esensial kenanga memungkinkan efek yang lebih baik daripada minyak esensial lavender.
\end{abstract}

Kata Kunci: slow stroke back massage, minyak esensial kenanga, minyak esensial lavender, tekanan darah, lansia

\begin{abstract}
Introduction: The high incidence of hypertension in elderly demands the role of health workers to make efforts to prevent complications that can arise due to hypertension, one of which is slow stroke back massage. The benefit of slow stroke back massage is to reduce tension and decrease the tolerance of pain and anxiety. This research aim to know the difference of effectiveness of slow stroke back
\end{abstract}


massage by using ylang essential oil (Cananga odorata) and lavender essential oil (Lavandula angustifolia) to decrease blood pressure in elderly with hypertension. Method: This research was used control group pretest posttest design. The number of samples in this study were 30 samples which is divided into 2 groups each consisting of 15 respondents determined by purposive sampling technic. Result: After test of Independent T-Test the results showed the sistole blood pressure got significance $0.000<0,05$ which mean there is a difference decreased of sistole blood pressure after giving slow stroke back massage by using ylang and lavender essential oil, whereas at diastolic blood pressure got significance $0.001<0.05$ which means there is a difference decreased in diastolic blood pressure after giving slow stroke back massage using ylang and lavender essential oil. Discussion: The eugenol effect was found only in the ylang essential oil which allows for a better effect than the lavender essential oil.

Keywords: slow stroke back massage, ylang essential oil, lavender essential oil, blood pressure, elderly

\begin{tabular}{ll}
\hline Alamat Korespondensi & $\begin{array}{l}\text { : Jalan Gandapura IV A No. 16 Kesiman Denpasar Timur, } \\
\text { Denpasar Bali } \\
\text { Email }\end{array}$ \\
\hline
\end{tabular}

\section{PENDAHULUAN}

Proses penuaan akan berdampak pada berbagai aspek kehidupan seperti aspek sosial, ekonomi maupun aspek kesehatan. Ditinjau dari aspek kesehatan bertambahnya usia menyebabkan lansia lebih rentan terhadap berbagai keluhan fisik dan psikis, baik karena faktor alamiah maupun karena penyakit (Depkes RI, 2015). Salah satu gangguan kesehatan yang banyak dialami lansia adalah hipertensi (Mubarak, 2006). Banyak lansia yang menderita hipertensi tetapi tidak menyadarinya, hal ini disebabkan karena hipertensi ringan tidak akan menimbulkan tanda dan gejala yang khas. Penyakit ini berjalan terus seumur hidup dan sering tanpa adanya keluhan yang khas selama belum ada komplikasi pada organ tubuh. Hipertensi merupakan penyakit yang tidak dapat disembuhkan melainkan hanya dapat dikontrol (Vitahealth, 2010). World Health Organization (WHO) (2013), menyatakan prevalensi hipertensi diperkirakan akan terus meningkat, dan diprediksi pada tahun 2025 sebanyak $29 \%$ orang dewasa di seluruh dunia menderita hipertensi. Secara keseluruhan, WHO melaporkan negara-negara berpendapatan tinggi memiliki jumlah penderita hipertensi yang lebih rendah dibandingkan negara-negara berpendapatan rendah dan menengah. Diperkirakan sejumlah 36\% orang dewasa di Kawasan Asia Tenggara menderita hipertensi dan penyakit ini telah membunuh 1,5 juta orang setiap tahunnya (Schlein, 2013). Prevalensi penderita hipertensi di Indonesia menurut Depkes RI tahun 2013, hipertensi termasuk 10 besar penyakit terbanyak lansia tahun 2013, kelompok umur 55-64 tahun sebanyak 45,9\%, umur 65-74 tahun sebanyak 57,6\%, dan umur 75 tahun ke atas 63,8\% (Riskesdas, 2013), sedangkan data dinas kesehatan Provinsi Bali tentang penyakit tidak menular (PTM), mencatat jumlah kasus hipertensi pada lansia tahun 
2012 sebanyak 22.837 kasus, tahun 2013 sebanyak 29.867 kasus dan tahun 2014 sebanyak 34.421 kasus (Profil Kesehatan Dinas Provinsi Bali, 2014).

Tingginya angka kejadian hipertensi pada lansia menuntut peran tenaga kesehatan untuk melakukan upaya pencegahan komplikasi yang dapat timbul akibat hipertensi seperti stroke, serangan jantung, gagal ginjal dan kerusakan penglihatan. Sampai saat ini banyak peneliti yang mengembangkan pengobatan secara non farmakologi untuk mengendalikan tekanan darah pada penderita hipertensi. Beberapa penelitian menunjukkan bahwa pendekatan nonfarmakologis dapat dilakukan pada penderita hipertensi yaitu meliputi; teknik-teknik mengurangi stres, penurunan berat badan, pembatasan alkohol, natrium, dan tembakau, olahraga atau latihan yang berefek meningkatkan lipoprotein berdensitas tinggi, dan relaksasi yang merupakan intervensi wajib yang harus dilakukan pada setiap terapi hipertensi (Muttaqin, 2009). Olney (2005) dalam penelitiannya mendapatkan hasil bahwa masase dapat menurunkan tekanan darah sistolik dan diastolik pada penderita hipertensi. Penelitian Meek didapatkan hasil bahwa implikasi keperawatan slow stroke back massage dapat menurunkan tekanan darah, frekuensi jantung dan suhu tubuh. Manfaat dari penggunaan teknik slow stroke back massage adalah pasien dapat merasa lebih nyaman, mengurangi ketegangan yang dapat menurunkan toleransi nyeri serta dapat menurunkan ansietas (Smeltzer dan Bare, 2008).

Mekanisme slow stroke back massage (pijat lembut pada punggung) yaitu meningkatkan relaksasi dengan menurunkan aktivitas saraf simpatis dan meningkatkan aktivitas saraf parasimpatis sehingga terjadi vasodilatasi diameter arteriol (Cassar, 2004). Sistem saraf parasimpatis melepaskan neurotransmiter asetilkolin untuk menghambat aktifitas saraf simpatis dengan menurunkan kontraktilitas otot jantung, volume sekuncup, vasodilatasi arteriol dan vena kemudian menurunkan tekanan darah (Muttaqin, 2009).

Bunga kenanga mengandung saponin, flavonoida, poilifenol dan minyak atsiri. Minyak kenanga terutama dipergunakan di dalam pembuatan aneka produk wangi-wangian, sangat baik untuk terapi aroma (aromatheraphy), karena ia akan mengatur aliran kelenjar andrenalin dalam sistem saraf sehingga menimbulkan rasa senang, tenang, menghilangkan gelisah, marah, dan panik (Pujiarti, Widowati, Kasmudjo, \& Sunarta, 2015). Minyak lavender dengan kandungan linalool-nya adalah salah satu minyak aromaterapi yang banyak digunakan saat ini, baik secara inhalasi (dihirup) ataupun dengan teknik pemijatan pada kulit. Beberapa tetes minyak lavender dapat membantu menanggulangi insomnia, memperbaiki mood seseorang, dan memberikan efek relaksasi. Penelitian lain mengenai efek aromaterapi lavender untuk relaksasi, kecemasan, mood, dan kewaspadaan pada aktivitas EEG (Electro Enchepalo Gram) menunjukkan terjadinya penurunan kecemasan, perbaikan mood, dan terjadi peningkatan kekuatan gelombang alpha dan beta pada EEG yang menunjukkan peningkatan relaksasi (Diego, et al., 1998).

Peneliti dalam penelitian ini membandingkan penggunaan minyak esensial lavender dan minyak esensial kenanga dalam pemberian terapi slow stroke back massage untuk menurunkan tekanan darah pada penderita hipertensi, dikarenakan terapi relaksasi tersebut merupakan cara yang mudah, sederhana dan murah. Teknik ini dapat dilakukan oleh perawat dan dapat diajarkan kepada keluarga pasien. 


\section{METODE}

Penelitian ini merupakan penelitian pre-eksperimental design, dengan menggunakan rancangan control group pretest-posttest design. Jumlah sampel dalam penelitian ini adalah 30 orang yang dibagi menjadi dua kelompok yaitu perlakuan dan kontrol dengan jumlah masing-masing 15 responden yang dipilih dengan metode purposive sampling.

\section{HASIL}

1. Tekanan Darah Sistole-Diastole sebelum dan setelah diberikan slow stroke back massage dengan minyak esensial Kenanga

Tabel 1. Identifikasi tekanan darah sistole-diastole sebelum dan setelah diberikan slow stroke back massage dengan menggunakan minyak esensial Kenanga pada Kelompok Kenanga $(n=15)$

\begin{tabular}{lcccc}
\hline $\begin{array}{l}\text { Kelompok } \\
\text { Kenanga }\end{array}$ & $\begin{array}{c}\text { Min- } \\
\text { Max }\end{array}$ & Mean & $\begin{array}{c}\text { Std. } \\
\text { Deviation }\end{array}$ \\
\hline $\begin{array}{l}\text { Pre } \\
\text { Sistole }\end{array}$ & Test & $\begin{array}{c}140- \\
180\end{array}$ & 157,33 & 12,228 \\
\hline $\begin{array}{l}\text { Post } \\
\text { Sistole }\end{array}$ & Test & $\begin{array}{c}130- \\
170\end{array}$ & 144,67 & 11,255 \\
\hline $\begin{array}{l}\text { Pre } \\
\text { Diastole }\end{array}$ & Test & $90-115$ & 100,33 & 7,898 \\
\hline $\begin{array}{l}\text { Post } \\
\text { Diastole }\end{array}$ & Test & $80-110$ & 91,33 & 7,898 \\
\hline
\end{tabular}

Tabel 1 menunjukkan sebelum diberikan terapi pada Kelompok Kenanga, rata-rata tekanan darah sistole yaitu 157,33 $\pm 12,228$ dan rata-rata tekanan darah diastole yaitu $100,33 \pm 7,898$. Setelah diberikan terapi pada Kelompok Kenanga, rata-rata tekanan darah sistole yaitu $144,67 \pm 11,255$ dan rata-rata tekanan darah diastole yaitu $91,33 \pm 7,898$.

2. Tekanan Darah Sistole-Diastole sebelum dan setelah diberikan slow stroke back massage dengan minyak esensial lavender

Tabel 2. Identifikasi tekanan darah sistole-diastole sebelum dan setelah diberikan slow stroke back massage dengan menggunakan minyak esensial lavender pada Kelompok Lavender $(n=15)$

\begin{tabular}{cccc}
\hline $\begin{array}{c}\text { Kelompok } \\
\text { Lavender }\end{array}$ & $\begin{array}{c}\text { Min- } \\
\text { Max }\end{array}$ & Mean & $\begin{array}{c}\text { Std. } \\
\text { Deviation }\end{array}$ \\
\hline Pre Test & $140-$ & 152,67 & 10,238 \\
Sistole & 170 & & \\
\hline Post Test & $130-$ & 151,33 & 12,459 \\
Sistole & 170 & & \\
\hline Pre Test & $90-$ & 99,67 & 7,188 \\
Diastole & 115 & & \\
\hline Post Test & $90-$ & 100,33 & 7,898 \\
Diastole & 115 & & \\
\hline
\end{tabular}


Pada table 2 dapat dilihat pada hari pertama dilakukan pengukuran tekanan darah pada Kelompok Lavender, rata-rata tekanan darah sistole yaitu 152,67 $\pm 10,238$ dan rata-rata tekanan darah diastole yaitu $99,67 \pm 7,188$. Setelah diberikan terapi dilakukan pengukuran tekanan darah pada Kelompok Lavender, rata-rata tekanan darah sistole yaitu $151,33 \pm 12,459$ dan rata-rata tekanan darah diastole yaitu $100,33 \pm 7,898$.

3. Hasil analisa perbedaan tekanan darah sistole-diastole sebelum dan setelah diberikan slow stroke back massage dengan menggunakan minyak esensial kenanga pada Kelompok Kenanga

Tabel 3. Hasil Analisa Perbedaan Tekanan Darah Sistole-Diastole Sebelum Dan Setelah Diberikan Slow Stroke Back Massage Dengan Menggunakan Minyak Esensial Kenanga

\begin{tabular}{lcccc}
\hline Kelompok & Delta & $\begin{array}{l}\text { Standar } \\
\text { Deviasi }\end{array}$ & T & $p$.value \\
\hline $\begin{array}{l}\text { Pre kenanga } \\
\text { Sistole }-\end{array}$ & 12,667 & 7,037 & 6,971 & 0,000 \\
$\begin{array}{l}\text { Post kenanga } \\
\text { Sistole }\end{array}$ & & & & \\
\hline $\begin{array}{l}\text { Pre kenanga } \\
\text { Diastole - } \\
\text { Post kenanga } \\
\text { Diastole }\end{array}$ & 9,000 & 7,838 & 4,447 & 0,001 \\
\hline
\end{tabular}

Tabel 3 menunjukkan ada perbedaan yang signifikan tekanan darah sistole sebelum dan setelah diberikan slow stroke back massage pada kelompok kenanga, sedangkan nilai $p$ value tekanan darah diastole adalah $0,001<0,05$ berarti ada perbedaan yang signifikan tekanan darah diastole sebelum dan setelah diberikan slow stroke back massage pada kelompok kenanga.

4. Hasil analisa perbedaan tekanan darah sistole-diastole sebelum dan setelah diberikan slow stroke back massage dengan menggunakan minyak esensial Lavender pada Kelompok Lavender

Tabel 4. Hasil Analisa Perbedaan Tekanan Darah Sistole-Diastole Sebelum Dan Setelah Diberikan Slow Stroke Back Massage Dengan Menggunakan Minyak Esensial Lavender

\begin{tabular}{lcccc}
\hline Kelompok & Delta & $\begin{array}{l}\text { Standar } \\
\text { Deviasi }\end{array}$ & T & $p$.value \\
\hline $\begin{array}{l}\text { Pre lavender } \\
\text { Sistole }-\end{array}$ & 1,333 & 7,432 & 0,695 & 0,049 \\
$\begin{array}{l}\text { Post lavender } \\
\text { Sistole }\end{array}$ & & & & \\
\hline $\begin{array}{l}\text { Pre lavender } \\
\text { Diastole }-\end{array}$ & $-0,667$ & 6,230 & $-0,414$ & 0,685 \\
$\begin{array}{l}\text { Post lavender } \\
\text { Diastole }\end{array}$ & & & & \\
\hline
\end{tabular}


Tabel 4 menunjukkan hasil uji statistik Paired T Test, diperoleh nilai $p$ value tekanan darah sistole adalah 0,499 >0,05 berarti ada perbedaan yang signifikan tekanan darah sistole sebelum dan setelah diberikan slow stroke back massage pada pada Kelompok Lavender, sedangkan nilai $p$ value tekanan darah diastole adalah $0,685>0,05$ berarti $\mathrm{H}_{0}$ diterima $\mathrm{H}_{\mathrm{a}}$ ditolak yang berarti tidak ada perbedaan yang signifikan tekanan darah diastole sebelum dan setelah diberikan slow stroke back massage pada pada Kelompok Lavender.

\section{Hasil analisa pengaruh slow stroke back massage terhadap penurunan tekanan darah sistole-diastole pada kelompok kenanga dan Kelompok Lavender}

Tabel 5. Hasil Analisa Pengaruh Slow Stroke Back Massage Terhadap
Penurunan Tekanan Darah Sistole-Diastole Pada Kelompok Eksperimen Dan
Kelompok Lavender

\begin{tabular}{|c|c|c|c|c|}
\hline \multicolumn{2}{|c|}{ Kelompok } & $\mathbf{N}$ & Mean & p. value \\
\hline \multirow{2}{*}{$\begin{array}{l}\text { Selisih } \\
\text { Sistole }\end{array}$} & Eksp. & \multirow{2}{*}{15} & \multirow{2}{*}{11,333} & \multirow{2}{*}{0,000} \\
\hline & Kont. & & & \\
\hline \multirow{2}{*}{$\begin{array}{c}\text { Selisih } \\
\text { Diastole }\end{array}$} & Eksp. & \multirow{2}{*}{15} & \multirow{2}{*}{9,667} & \multirow{2}{*}{0,001} \\
\hline & Kont. & & & \\
\hline
\end{tabular}

Table 5 menunjukkan hasil uji Independent $T$ Test pada tekanan darah sistole didapatkan signifikansi $0,000<0,05$ yang berarti perbedaan penurunan tekanan darah sistole setelah pemberian slow stroke back massage dengan menggunakan minyak esensial kenanga dan lavender, sedangkan pada tekanan darah diastole didapatkan signifikansi $0,001<0,05$ yang berarti ada perbedaan penurunan tekanan darah diastole setelah pemberian slow stroke back massage dengan menggunakan minyak esensial kenanga dan lavender.

\section{PEMBAHASAN}

Secara teori dan klinis, tidak ada perbedaan yang signifikan dari tekanan darah pada laki-laki atau perempuan. Terjadinya hipertensi disebabkan oleh berbagai faktor yaitu merokok, konsumsi alkohol, diet tinggi natrium, dan stress (Healey, 2011). Jenis makanan yang menyebabkan hipertensi yaitu makanan yang siap saji yang mengandung pengawet, kadar garam yang terlalu tinggi dalam makanan, kelebihan konsumsi lemak (Susilo, 2011).

Berdasarkan penelitian yang dilakukan oleh peneliti, didapatkan hasil bahwa responden sering mengalami stress dan memakan makanan tinggi lemak. Sebagian besar lansia mengatakan sering mengkonsumsi makanan tinggi lemak seperti babi guling atau babi genyol. Tingkat stress yang sering terjadi akibat ketidakmampuan responden untuk melakukan apapun yang diinginkan sendiri melainkan harus dibantu orang lain atau keluarga.

Apabila stress menjadi berkepanjangan dapat berakibat tekanan darah menjadi tetap tinggi. Stres dapat merangsang kelenjar anak ginjal melepaskan 
hormone adrenalin dan memacu jantung berdenyut lebih cepat serta lebih kuat, sehingga tekanan darah akan meningkat. Jika stress berlangsung cukup lama, tubuh berusaha mengadakan penyesuaian sehingga timbul kelainan organis atau perubahan patologis (Sugiharto, 2007).

Menurut Lewa (2010), pada sebagian besar usia lanjut sering terjadi hipertensi sedang sampai berat. Penelitian ini sesuai dengan penelitian yang dilakukan oleh Retno (2012), yang menunjukkan bahwa slow stroke back massage dapat membantu menurunkan tekanan darah pada hipertensi. Secara teori, umur merupakan salah satu faktor resiko hipertensi yang tidak dapat dikontrol. Semakin bertambah umur seseorang semakin tinggi tekanan darahnya, jadi orang yang lebih tua cenderung mempunyai tekanan darah yang tinggi dari orang yang berusia lebih muda. Hal ini disebabkan karena arteri kehilangan elastisitas atau kelenturan serta tekanan darah meningkat seiring dengan bertambahnya usia. Berdasarkan hasil yang didapatkan oleh peneliti pada saat mengukur tekanan darah responden, didapatkan hasil bahwa semua lansia yang mengalami hipertensi berumur diatas 60 tahun yakni sebanyak 30 responden dari 30 sampel yang diteliti pada kelompok kenanga dan kelompok lavender . Prevalensi di kalangan usia lanjut cukup tinggi yaitu sekitar 40\% dengan kematian sekitar 50\% diatas umur 60 tahun (Elsanti, 2009). Berdasarkan hasil penelitian Sucipto (2012), dinyatakan bahwa jumlah lansia yang menderita hipertensi dengan umur diatas 60 tahun lebih banyak dari pada yang berumur dibawah 60 tahun yakni 16 responden dari 18 sampel yang diteliti.

Beberapa penelitian menunjukkan bahwa pendekatan nonfarmakologi dapat dilakukan pada penderita hipertensi yaitu meliputi teknik-teknik mengurangi stress, penurunan berat badan, pembatasan alkohol, natrium, dan tebakau. Olahraga atau latihan dan relaksasi yang merupakan intervensi wajib yang harus dilakukan pada setiap terapi hipertensi, salah satunya adalah slow stroke back massage (Muttaqin, 2009).

Secara konsep, slow stroke back massage dapat menurunkan tekanan darah sistole-diastole karena membantu memperbaiki sirkulasi, karena sirkulasinya membaik, maka pada akhirnya organ-organ yang ada di dalam tubuh akan berfungsi dan bekerja dengan baik. Efek penurunan tekanan darah dari slow stroke back massage didapatkan melalui peningkatan vasodilatasi pembuluh darah dan dapat mengurangi rasa nyeri kepala akibat hipertensi, sehingga komplikasi lebih lanjut dapat dicegah (Arifin, 2012).

Secara teori, slow stroke back massage merupakan gerakan sentuhan dan penekanan pada kulit area punggung yang memberikan efek relaksasi pada otot, tendon dan ligamen. Terapi ini memiliki efek relaksasi dengan menurunkan aktivitas saraf simpatis dan meningkatkan saraf parasimpatis sehingga terjadi vasodilatasi arteriol kemudian menurunkan tekanan darah. Selain itu, gosokan punggung yang sederhana dan halus dari terapi ini dapat meningkatkan kenyamanan dan relaksasi, serta memiliki efek positif pada parameter kardiovaskuler seperti tekanan darah, frekuensi denyut jantung, dan frekuensi pernafasan. Selain itu, terapi ini juga dapat merangsang pengeluaran hormon endhorpine. Hormon ini dapat memberikan efek tenang pada pasien dan terjadi vasodilatasi pada pembuluh darah sehingga pembuluh darah menjadi rileks dan akan menyebabkan penurunan tekanan darah (Retno, 2012). 
Sementara itu, bila minyak esensial dengan aroma digunakan untuk slow stroke back massage, akan menimbulkan efek relaksasi yang akan merangsang kerja endorphin pada kelenjar pituitary. Beta endorphin memiliki efek positif pada tubuh dan pikiran dimana saat beta endorphin dilepaskan tekanan darah akan turun (Sholikha, 2011). Berdasarkan hasil penelitian yang dilakukan Retno (2012), didapatkan hasil tekanan darah mengalami penurunan yang signifikan setelah diberikan slow stroke back massage.

Dilihat dari hasil penelitian dan teori yang menjelaskan terkait dengan pengaruh slow stroke back massage dengan menggunakan minyak esensial, maka peneliti berpendapat adanya perbedaan nilai tekanan darah sistole-diastole sebelum dan setelah diberikan slow stroke back massage dengan menggunakan minyak esensial disebabkan karena efek slow stroke back massage dan juga efek minyak esensial yang dapat meningkatkan respon rilek pada responden. Selain itu, perbedaan nilai tekanan darah sistole-diastole dipengaruhi karena slow stroke back massage dilakukan dengan menggunakan minyak esensial sehingga dapat memberikan efek ganda untuk menurunkan tekanan darah pada responden.

Minyak lavender dengan kandungan linalool-nya adalah salah satu minyak aromaterapi yang banyak digunakan saat ini, baik secara inhalasi (dihirup) ataupun dengan teknik pemijatan pada kulit. Manfaat lain bunga lavender adalah dapat dijadikan minyak esensial yang sering dipakai sebagai aromaterapi karena dapat memberikan manfaat relaksasi dan memiliki efek sedasi yang sangat membantu pada orang yang mengalami insomnia. Berdasarkan data di atas, dapat disimpulkan bahwa kandungan utama dari bunga lavender adalah linalyl asetat dan linalool (C10H18O). Linalyl asetat sebagai salah satu kandungan utama pada lavender tidak menghasilkan efek anti cemas.

Minyak kenanga terutama dipergunakan didalam pembuatan aneka produk wangi-wangian, sangat baik untuk terapi aroma (aromatheraphy), karena bunga kenanga mengandung saponin, flavonoida, poilifenol, minyak atsiri, kandungan linalool, geraniol, dan eugenol yang dapat mengatur aliran kelenjar andrenalin dalam sistem saraf sehingga menimbulkan rasa senang, tenang, menghilangkan gelisah, marah, dan panik. kandungan linalool baik pada lavender maupun kenanga memberikan hasil yang signifikan yang menunjukkan kandungan aktif utama yang berperan pada efek anti cemas (relaksasi) pada lavender (Dewi, 2013). Eugenol sedikit larut dalam air namun mudah larut pada pelarut organik. Aromanya menyegarkan dan pedas seperti bunga cengkeh kering, sehingga sering menjadi komponen untuk menyegarkan mulut. Komponen yang mempunyai sifat sebagai stimulan, anestetik lokal, karminatif, antiemetik, antiseptik dan antispasmodik.

Efek eugenol yang hanya terdapat pada minyak esensial kenanga memungkinkan efek yang lebih baik daripada minyak esensial lavender. Penurunan tekanan darah tersebut dikarenakan oleh menurunnya aktivitas saraf simpatis sebagai efek antispasmodik dari minyak esensial kenanga sehingga meningkatkan saraf parasimpatis dan terjadi vasodilatasi akibat rangsangan slow stroke back massage serta timbulnya efek relaksasi yang akan merangsang kerja endorphin pada kelenjar pituitary karena efek minyak esensial kenanga. Efek slow stroke back massage dan juga efek minyak esensial kenanga dapat meningkatkan respon rileks pada responden dan dapat memberikan efek ganda untuk menurunkan tekanan darah pada responden. Berdasarkan hal tersebut peneliti berpendapat bahwa banyak jenis terapi non farmakologi yang dapat menurunkan tekanan darah pada lansia 
seperti meditasi, akupuntur, akupresur, dan konsumsi obat herbal. Namun slow stroke back massage dengan menggunakan minyak esensial lebih mudah, murah, dan aman bila diterapkan pada lansia sehingga dapat dianjurkan bagi lansia dengan hipertensi

\section{Simpulan}

\section{SIMPULAN DAN SARAN}

Setelah diberikan terapi dengan minyak esensial kenanga, rata-rata tekanan darah sistole yaitu 144,67 $\pm 11,255$ dan rata-rata tekanan darah diastole yaitu 91,33 $\pm 7,898$. Setelah diberikan terapi dengan minyak esensial lavender, rata-rata tekanan darah sistole yaitu $151,33 \pm 12,459$ dan rata-rata tekanan darah diastole yaitu $100,33 \pm 7,898$. Terdapat perbedaan yang signifikan tekanan darah systole maupun diastole sebelum dan setelah diberikan slow stroke back massage pada kelompok kenanga.

Terdapat perbedaan yang signifikan tekanan darah sistole sebelum dan setelah diberikan slow stroke back massage pada pada Kelompok Lavender, sedangkan tidak ada perbedaan yang signifikan tekanan darah diastole sebelum dan setelah diberikan slow stroke back massage pada pada Kelompok Lavender. Terdapat perbedaan penurunan tekanan darah sistole maupun diastole setelah pemberian slow stroke back massage dengan menggunakan minyak esensial kenanga dan lavender.

\section{Saran}

Peneliti menyarankan agar penelitian ini dapat diaplikasikan dalam program pengabdian masyarakat bagi sivitas STIKes Wira Medika Bali dengan bentuk pemberian penyuluhan, pelatihan, dan penerapan metode non farmakologi (terapi slow stroke back massage) dalam menurunkan tekanan darah pada lansia dengan hipertensi guna meningkatkan kesehatan masyarakat. Selanjutnya diharapkan hasil penelitian ini dapat menjadi bahan acuan dalam meneliti lebih lanjut tentang terapi komplementer lain bagi penderita hipertensi, terutama yang berhubungan dengan body mechanic, dengan mengkombinasikan pemberiannya dengan minyak essensial yang lain serta memperhatikan faktor-faktor yang mempengaruhi hipertensi seperti diet tinggi natrium, stress, kafein, obesitas dan lainnya.

\section{DAFTAR PUSTAKA}

Adhitama, S. 2010. Krisis Hipertensi Asfek Klinis dan Pengobatan. Jakarta : Bagian Fisiologi Universitas Kedokteran Sumatra Utara

Adhyati, S.(2011). Pengaruh Stimulasi Kuntaneus Slow Stroke Back Massage Terhadap Intensitas Nyeri pada Penderita Low Back Pain di Kelurahan Aek Gerger Sidodadi. Skripsi. Medan: Fakultas Keperawatan Universitas Sumatra Utara.

Arifin, dkk. 2012. Jurnal Fakultas Keperawatan Universitas Airlangga. Perbedaan Communication Back Massage Dan Back Massage Dalam Menurunkan Tekanan Darah Pada Klien Dengan Lansia Dengan Hipertensi. Fakultas Keperawatan Universitas Airlangga Surabaya. Surabaya.

Arisanti, A. 2012. Pengaruh Slow Stroke Back Massage Terhadap Kecemasan Ibu 
Menopaus Di Jember Lor Wilayah Kerja Puskesmas Patrang Kabupaten Jember. Program Studi Ilmu Keperawatan Universitas Jember.

Arthini, dkk. 2012. Pengaruh Massage Terhadap Tekanan Darah Sistolik Pada Lansia Di Panti Sosial Tresna Werdha Wana Seraya Denpasar.

Azizah, L. (2011). Keperawatan lanjut usia. Edisi 1. Yogyakarta: Graha Ilmu.

Cassar, M. 2004. Handbook of Clinical Massage: A Complete Guide for Students and Practitioners. Amerika Serikat: Elsevier.

Departemen Kesehatan RI. 2015. Profil Kesehatan Indonesia Tahun 2014. Jakarta: Kemenkes RI; 2015.

Dinas Kesetahan Provinsi 2014. http://www.diskes.baliprov.go.id/id/PROFIL-KESEHATAN-PROVINSIBALI2 (diakses 3 Maret 2017).

Elsanti D.A. 2009. Pengaruh Aktifitas Fisik Terhadap Tekanan Darah. Majalah Kedokteran Atmajaya, Volume 4, Nomor 2.

Healey, Dale DC. 2011. How Does Massage Works? http://takingcharge.csh.umm.edu/explore-healing-practices/massagetherapy/how-does-massage-work

Kemenkes RI. 2014. Infodatin Hipertensi. Jakarta : Kementerian Kesehatan Republik Indonesia.

Kowalski, R.E. (2010). Terapi hipertensi. Bandung: Qanita.

Kozier. 2009. Buku Ajar Fundamental Keperawatan: Konsep, Proses, dan Praktik. Edisi Kelima. Jakarta : EGC.

Kuswardhani, Tuty. 2006. Penatalaksanaan Hipertensi pada Lanjut Usia. Denpasar : Universitas Udayana.

Lewa, AF, dkk. 2010. Faktor-Faktor Risiko Hipertensi Sistolik Terisolasi Pada Lanjut Usia. http://jurnal.ugm.ac.id/bkm/article/view/3456/2983.pdf (diakses 20 April 2017).

Muhammadun. 2010. Hidup Bersama Hipertensi. Yogyakarta: In Book.

Muttaqin, Arif. 2009. Buku Ajar Asuhan Keperawatan Klien Dengan Gangguan Sistem Kardiovaskular Dan Hematologi. Jakarta : Salemba

Notoatmojo, S. 2012. Metodologi Penelitian Kesehatan. Jakarta: Renika Cipta.

Nugroho, H. Wahjudi. 2014. Keperawatan Gerontik dan Geriatrik Edisi 3. Jakarta : EGC

Nursalam. 2008. Konsep \& Penerapan Metodologi Penelitian Ilmu Keperawatan: Pedoman Skripsi, Tesis dan Instrumen Penelitian Keperawatan. Jakarta, Salemba Medika. . 2013. Konsep dan Penerapan Metodologi Penelitian Ilmu Keperawatan: Pedoman Skripsi, Tesis, dan Instrumen Penelitian Keperawatan. Jakarta: Salemba Medika. . 2016. Metodologi Penelitian Ilmu Keperawatan : Pendekatan Praktis Edisi 4. Jakarta, Salemba Medika.

Olney,C,M. 2005. The Effect Of Therapeutic Back Massage In Hypertensive Persons: A Preliminary Study. Biological Research For Nursing

Potter, P.A \& Perry. A.G. 2006. Buku Ajar Fundamental Keperawatan :Konsep, Proses dan Praktek, Vol 2,Edisi 4 alih Bahasa Yasmin A. Jakarta : EGC.

Primayanthi. 2016. Pengaruh Terapi Slow Stroke Back Massage Dengan Minyak Esensial Lavender Terhadap Penurunan Intensitas Nyeri Low Back Pain. Program Studi Ilmu Keperawatan Fakultas Kedokteran Udayana. 
Rachamawati, Yuliana Dewi. 2013. Hubungan Antara Gaya Hidup Dengan Kejadian Hipertensi Pada Usia Dewasa Muda Di Desa Pondok Kecamatan Nguter Kabupaten Sukoharjo. Program Studi Kesehatan Masyarakat Fakultas Ilmu Kesehatan Universitas Muhammadiyah Surakarta.

Retno A.W \& Prawest, D. 2012. Tindakan Slow Stroke Back Massage Dalam Menurunkan Tekanan Darah Pada Penderita Hipertensi. Jurnal STIKES Volume 5, No 2. STIKES Baptis Kediri. http://puslit2.petra.ac.id/ejournal/index.php/stikes/18610/18370 (diakses 20 April 2017).

Shinta, A. 2014. Pemberian Intervensi Slow Stroke Back Massage Menurunkan Tekanan Darah pada Wanita Middle Age dengan Kondisi Pre-Hypertension di Banjar Batan Buah, Desa Kesiman. Program Studi Fisioterapi Fakultas Kedokteran Universitas Udayana.

Sholikha, M. 2011. Pemakaian Minyak Esensial Secara Inhalasi. Program Magister Herbal Departemen Farmasi Fakultas Matematika dan Ilmu Pengetahuan Alam Universitas Indonesia .

Smeltzer, S.C., Bare, B.G. 2008. Buku Ajar Keperawatan Medikal Bedah Brunner \& Suddarth; volume 2. Jakarta: EGC.

Stanley \& Beare. 2007. Buku Ajar Keperawatan Gerontik. Edisi 2. Jakarta : EGC.

Sucipto, Adi. 2012. Pengaruh Teknik Relaksasi Otot Progresif Terhadap Tekanan Darah Pada Lansia Dengan Hipertensi Di Desa Karangbendo Banguntapan Bantul Yogyakarta.

Sugiharto, Aris. 2007. Faktor-Faktor Resiko Hipertensi Grade II Pada Masyarakat. Universitas Diponogoro Semarang

Sugiono. 2011. Metodelogi Penelitian Kualitatif \& Kuantitatif. Bandung. Cv Alfabeta.

Suoth, Meylen. 2014. Hubungan Gaya Hidup Dengan Kejadian Hipertensi Di Puskesmas Kolongan Kecamatan Kalawat Kabupaten Minahasa Utara. Program Studi Ilmu Keperawatan Fakultas Kedokteran Universitas Sam Ratulangi Manado.

Susilo, Yekti dan Wulandari Ari. (2011). Cara Jitu Mengatasi Hipertensi. Yogyakarta: C.V Andi Offset.

Suviani. 2014. Pengaruh Pemberian Aroma Terapi Lavender (Lavandula Angustifolia) Terhadap Penurunan Hipertensi Pada Lansia Di Desa Cemagi, Kecamatan Mengwi, Kabupaten Badung. STIKES Bina Usada Bali.

Vitahealth. 2010. Hipertensi. Jakarta: Gramedia.

Wijanarko dan Slamet Riyadi. 2010. Sport Massage Teori dan Praktik. Surakarta : Yuma Pustaka.

World Health Organization. 2015. A Global Brief on Hypertension: silent killer, global public health crisis. 